\title{
CLÁUSULA GERAL E SEGURANÇA JURÍdica NO CÓdIGO CIVIL
}

\author{
Paulo Nalin*
}

RESUMO: O trabalho enfrenta a polêmica técnica de cláusulas gerais, à qual recorre o Código Civil em vigor, em suas partes nucleares. A problemática segue na abordagem do desenvolvimento da técnica legislativa em questão, em face da operação do Código, num plano ético das relações jurídicas. Ao se tratar da operação do novo texto civil, passa-se à análise do (renovado) papel do juiz por força do Código, verticalizando-se o tema, ao final, na abordagem da fundamentação das decisões judiciais, em homenagem à manutenção da segurança jurídica.

INTRODUÇÃO: PROBLEMA E CRÍTICA

$\mathrm{O}$ assunto posto em análise encontra indisfarçável origem na codificação civil brasileira em vigor, apesar de o presente texto não guardar necessária aproximação a aspectos positivistas decorrentes da nova lei civil.

A preocupação da civilística, hoje, e que igualmente alcança grande parte dos magistrados que com o Direito Civil atuam, é com intenção de se conhecer a maneira mais adequada para se operar o novo código.

\footnotetext{
* Professor Adjunto de Direito Civil da UFPR. Professor Titular de Direito Civil da PUC-PR (licenciado). Mestre em Direito Privado - UFPR. Doutor em Direito das Relações Sociais - UFPR. Advogado.
}

O interesse não advém, de fato, da aplicação positiva do texto legal, mas sim da correta e, porque não dizer, ética operação do Código Civil (CC). Operar na base positiva o novo sistema civil não apresenta maiores desafios. Contudo, à mínima reflexão dos porquês de um novo $\mathrm{CC}$ e ao enfrentamento insuficiente da realidade social civil brasileira, com base na antiga codificação, percebe-se que a sociedade está por esperar muito mais do que uma neutra e fria subsunção lógica do caso à lei. É preciso um esforço maior, especialmente dos juízes, e o CC parece trazer elementos para uma virada tout à coup das práticas judiciais. A experiência (pragmática) do Direito já deu conta de ensinar que a lei em si não tem o condão de alterar a realidade da vida, sendo fundamental a participação do 
magistrado para fazer da lei um instrumento de mutação social.

Muitos juízes, legitimamente preocupados com as deficiências sociais de um país que tenta iniciar o terceiro milênio com mais dignidade humana geral, estão enxergando no CC um instrumento de renovação no estado das coisas, com o que estou de acordo. É porque a "crise judicial confina com a crise da lei", no entender de Luiz Fux (PÁDUA RIBEIRO, 2003, p.118), resultante da clássica inércia do Judiciário perante o fato social, aspecto que pode alcançar um novo colorido com o texto civil.

A problemática, portanto, localiza-se na operação sempre ética e alinhada com a proposta ideológica do novo Código, que vem a ser a sua (máxima) razão de existir.

Com o atual Código, a palavra ética ganha importância em nível de eficácia da própria lei, uma vez que a partir deste valor inerente à sociedade (trata-se, antes, de valor social do que jurídico) é que se erigiu e foi sancionada a Lei.$^{\circ} 10.406$, de 10 de janeiro de 2002. A justificativa axiológica para um novo Código encontra-se, nas palavras de Miguel Reale, sobretudo, na eticidade das relações civis, além de em outros valores, como o próprio codificador afirma, referido, para tanto, o art. 1131:

Desdobrando essa norma em seus elementos constitutivos, verifica-se que ela consagra a eleição específica dos negócios jurídicos como disciplina preferida para a regulação genérica dos fatos jurídicos, sendo fixada, desde logo, a eticidade de sua hermenêutica, em função da

1 Art. 113. Os negócios jurídicos devem ser interpretados conforme a boa-fé e os usos do lugar de sua celebração. boa-fé, bem como a sua socialidade, ao se fazer alusão aos "usos do lugar de sua celebração". (REALE, 2003, p.75)

A civilística, como um todo, tem enaltecido o profundo caráter ético do $\mathrm{CC}$, o que denota o trânsito entre o valor patrimonialista da codificação de 1916 e o atual vértice éticosocial da legislação aqui em apreço:

Em vários artigos pode-se observar, como uma das mais salientes características do novo Texto Civil, a valorização dos pressupostos éticos na ação dos sujeitos de direito, seja como conseqüência da proteção da confiança que deve existir como condição sine qua non da vida civil, seja como mandamento de equiidade, seja, ainda, como dever de proporcionalidade. (MARTINS-COSTA e BRANCO, 2002, p. 133)

Evidente, de outro lado, que o CC gravita ao redor de valores que não lhe pertencem, na origem intrínseca da lei, poị que são extraídos da sociedade e, logo, da própria Constituição da República. O CC recorre a eles (valores constitucionais) para executar o projeto maior da Carta Constitucional de 1988, no sentido de encampar valores como da repersonalização ${ }^{2}$ (FACHIN, 2000, p.14 e 15) e da despatrimonialização ${ }^{3}$ (PERLINGIERI,

2 Discorre o autor que repersonalizar implica recolocar a figura do "[...] indivíduo como ser coletivo, no centro dos interesses". Parafraseando Orlando de Carvalho, finaliza o autor, quando este último aborda o sentido e o limite de uma teoria geral da relação jurídica: "restaurar a primazia da pessoa é assim o dever número um de uma teoria do direito que se apresente como Teoria do Direito Civil'; e 'é esta centralização do regime em torno do homem e dos seus imediatos interesses que faz do Direito Civil o foyer da pessoa, do cidadão mediano, do cidadão puro e simples""

3 Alude o autor à originalidade da expressão "depatrimonializzazione" cunhada por Carmine Donisi, em 1980, consagrada que foi por Adriano De Cupis, em 1982. Mais relevante, explica Perlingieri 
1983, p. 176) do Direito Civil. Curioso, assim, imaginar que um projeto de lei (Projeto de Lei n. ${ }^{\circ} 635$, de 1975), ${ }^{4}$ do qual frutificou o novo Código, possa guardar tamanho alinhamento com o texto constitucional, sobretudo ao se recorrer à memória pouco (nada!) constitucional-democrática dos idos tempos das décadas de 1960 e 1970 . Ora, e com tais colocações, marca-se o compromisso com uma ética voltada ao sujeito de direito e não com aquela do mercado. Sim, porque mesmo os valores éticos que norteiam a sociedade brasileira têm sido manipulados ao sabor do mercado, por força de uma globalização acachapante e aniquiladora do

que "Con il termine, non certo elegante, di 'depatrimonializzazione' s'individua una tendenza normativo-culturale; s'indica, in definitiva, la consapevolezza che nel'ordinamento si è operata una scelta, che lentamente va attuandosi, tra personalismo (superamento dell individualismo) $e$ patrimonialismo (superamento della patrimonialità fine a se stessa, del produtivismo prima e del consumismo poi como valori)". Fundamental é a conclusão do autor, na seguinte passagem "Con ciò non si prospetta l'espulsione e la 'riduzione' quantitativa del contenuto patrimoniale nel sistema giuridico ed in quello civilistico in particolare; il momento economico, quale aspetto della realtà sociale organizzata, è ineliminabile. l...l". Tais conclusões são de completa aplicação ao sistema civil-constitucional brasileiro, pois a funcionalização social dos institutos jurídicos de caráter patrimonial traz consigo a essência do respeito por eles. Por força do art. 170 da Carta, especialmente de seu caput, é necessário encontrar a apropriada harmonia entre livre iniciativa e justiça social, pois, na moldura constitucional vigente, são elas faces complementares de uma mesma moeda.

4 Em verdade,-data de 1967 a Comissão nomeada pelo Governo Federal, para formular o Projeto de Código Civil, a qual era originalmente composta pelos juristas Miguel Reale (coordenador), José Carlos Moreira Alves, Agostinho Alvim, Sylvio Marcondes, Ebert Chamoun, Clóvis do Couto e Silva e Torquato Castro. ser, comprometidas com experiências culturais estrangeiras, as quais ditam as regras da ordem econômica. (COELHO, 2001, p.28)

Por tal razão, ainda que o CC atualmente seja uma verdadeira boa nova para o Direito brasileiro, não se pode atribuir a ele a centralidade do sistema, ainda que do assim referido "sistema privado", seja porque não é mais admissível uma dualidade entre sistemas jurídicos (público e privado), seja porque é a própria Constituição que está a ocupar a centralidade do sistema jurídico nacional, em torno da qual gravitam as demais fontes. Em extensão ao pensamento antes apresentado, parece estar, também, um tanto quanto em desarmonia com a supremacia hierárquica constitucional afirmar que o novo CC seria a "constituição do homem comum", da mesma forma que, há décadas, já se referiu a doutrina ao Código Civil de 1916 como se fosse ele a "Constituição do direito privado" (TEPEDINO, 1999, p.7).

Talvez, o Código Civil de 1916 possa ter motivado essa conotação de fonte maior para o cidadão comum, pois, naquela oportunidade, se vivia sob a égide da primeira Constituição Republicana Brasileira e, com isso, a dualidade dos sistemas (público e privado) era existente, o primeiro encabeçado pela Constituição, e o segundo, pelo Código Civil. Ainda que a Constituição sofra uma contínua mutação, por impulso jurisprudencial específico (BOLZAN DE MORAIS, 2000, p.21), evidencia-se do atual texto constitucional um Estado que busca concretizar um papel social, ou, viceversa, um Estado Social fruto de uma Constituição ocupada com a formação e o garantismo dos interesses do sujeito de direito, tanto quanto com as políticas do Estado. Explica Pietro Barcellona a distinção entre o Estado Social e o Estado de Direito: 
O Estado social comporta a superação da função garantidora da divisão dos poderes e pois da identificação do Estado com a sociedade. O Estado de direito pressupõe, ao invés, a separação entre Estado e sociedade civil. A fórmula do Estado de direito social pretende exprimir a reconciliação entre estas duas exigências, isto é, entre a exigência de superar o diafragma entre Estado e sociedade civil e a exigência de manter uma função garantidora. ${ }^{5}$ (BARCELLONA, 1996, p.113)

Por efeito, verifica-se, nos atuais dias, uma figura de Estado que não contrasta com a da sociedade, mas que com ela se identifica: a "constituição do homem comum" é a própria Constituição da República. Ela é a única Carta do Cidadão, não havendo espaço para o "cidadão civil", o "cidadão consumidor", o "cidadão trabalhista", ou qualquer outro, pois o sistema jurídico é uno e não fracionado:

Porque se o Direito, como Ciência, há de ser sistema de normas - e não somente conjunto de normas - no Direito em sentido objetivo como ordenamento jurídico -, em primeiro lugar, " não se trata de uma suma aritmética de suas partes, se não uma unidade na qual as partes se integram", como Santi Romano escreveu. ${ }^{6}$ (FLÓREZ-VALDÉS, 1991, p.174)

5 Tradução livre de "Lo Stato sociale comporta il superamento della funzione garantistica della divisione dei poteri e quindi la identificazione dello Stato con la società. Lo Stato de diritto presuppone, invece, la separazione tra Stato e società civile. La formula dello Stato di diritto sociale vuole esprimere il raccordo tra queste due esigenze, ciò̀ tra l'esigenza di superare il diaframma tra Stato e società civile e l'esigneza di mantenere una funzione garantistica."

6 Tradução livre de "Porque si el Derecho, como Ciencia, há de ser sistema de normas - y no sólo conjunto de normas - en el Derecho en sentido objetivo - como ordenamiento juridico -, en primer lugar; 'no se trata de una suma aritimética de sus partes, sino de una unidad en la que las partes se integran', como Santi Romano há escrito."
Nessa linha de pensar, não é de se admitir sistemas isolados, sub-sistemas e microssistemas, pois, especialmente estes últimos, cuja expressão tem sido inadvertidamente empregada por setores do Direito Contratual, vêm se pautando por uma "lógica do setor", incompatível com os fins de um sujeito constitucional. Natalino Irti, originariamente, advertia sobre os microssistemas:

[...] os microssistemas: conjunto de normas especiais que, ditadas por institutos singulares ou classes de relações, se encontram numa disciplina de princípios comuns. Se a uma nota diferenciadora sempre há posterior efeito, este diz que suscitou um novo critério de valoração, desencadeando, no âmbito do grande ordenamento jurídico, uma lógica de setor. ${ }^{7}$ (IRTI, 1986, p.65)

Essa lógica isolacionista (de setor) deve ser combatida, para ganhar peso o sujeito ou o cidadão constitucional, em qualquer segmento do Direito.

É com esse sujeito constitucional, cujo retrato estampa o CC, que anda preocupada a magistratura. Em outros termos, a sociedade brasileira recebeu um CC que busca trazer mais justiça social ao País, mas, de antemão, por força da praxis já consolidada ao longo do século XX, sabe-se que, infelizmente, a interação neutra do juiz com a lei, de modo a simplesmente admirar os processos judiciais, como se tudo ali realmente se passasse num Mundo do Direito, absolutamente ficto e

7 Tradução livre de "/.../ i micro-sistemi: insiemi di norme especiali, che, dettate per singoli instituti o classi rapporti, si ritrovano in comuni principi di disciplina. Se ad una nota differenziale tiene sempre dietro un effetto, questo dice che essa há suscitato un nuovo critero di valutazione, ha sprigionato, nell ambito del grande ordinamento giuridico, una logica di settore." 
distante da sua própria realidade como sujeito igualmente constitucional, não é suficiente para aniquilar as angústias do Poder Judiciário e, por que não dizer, da própria justiça.

Em vista disso, tão ou mais importante do que comentar artigos de lei do novo Código, ao menos nestes primeiros momentos da sua vigência, é examinar a técnica legislativa incorporada pelo $\mathrm{CC}$, em parte, diversa da anterior, a qual pode emancipar o juiz da sua condição de simples "boca que pronuncia a palavra da lei" e dele retirar a "[...] camisa-de-força teorética que o impede de descer à singularidade dos casos concretos e de sentir o pulsar da vida que neles se exprime, esse juiz, servo da legalidade e ignorante da vida, o mais que poderá fazer é semear a perplexidade social e a descrença na função que deveria encarar e que, por essa forma, nega. Negando-a, abre caminho para o desassossego social e a insegurança jurídica". (FARACO, 1989, p.25)

\section{A TÉCNICA DAS CLÁUSULAS GERAIS NO CÓDIGO CIVIL}

A esperança que alguns civilistas depositam na nova codificação encontra-se personificada na figura do juiz, pois a ele é dado operar as cláusulas gerais no texto legal, estrategicamente posicionadas no código, e que é a chave para a compreensão das potencialidades maiores da nova legislação civil.

O sentido do código, em verdade, não está nos dispositivos de lei descritivos e casuísticos, mas sim naqueles que provocam o juiz a "descer à singularidade do caso concreto", como afirma Plauto Faraco de
Azevedo, e que hoje se mostra possível por força das cláusulas gerais.

Porém, antes de ingressar em planos internos e descritivos sobre a técnica legislativa em questão, torna-se relevante indagar se ela, de fato, desponta como algo novo no cenário legislativo. E a resposta se apresenta como negativa; ou seja, esta técnica existe no sistema legal brasileiro, aparentemente, no plano temporal mais recente, alusivo aos $\operatorname{anos} 70$, momento no qual se viu o legislador encarregado de produzir grandes modificações legislativas de impacto social, sendo que, para tanto, recorreu a critérios menos descritivos da norma.

A notícia histórica sobre as cláusulas gerais, por certo, se aprofunda no tempo, em origem ainda mais remota, como assevera a doutrina italiana:

Analogia, clausole generali ed equità sono strumenti antichissimi nati sul terreno del diritto privato romano e coltivati dai prudentes per adeguare il primitivo ius civile non soltanto alle esigenze morali, ma anche a quelle sociali fin da allora in continua pur se diversa evoluzione. (GIULIANI, PALAZZO e FERRANTI, 1996, p.34)

E os mesmos autores, antes citados, destacam, contudo, que o uso da expressão "clausole generali" é de natureza contemporânea, pois naquela época era reconhecida tipicamente pelos critérios de interpretação e conduta do argumentum a simili, da fides e da bona fides (Op. cit, p.34 e 35).

Retornando ao Brasil, observa-se que o próprio Código Comercial recorria ao uso da técnica legislativa sob análise, ao se referir à boa-fé, embora ela jamais tenha sido empregada, diante da "compreensível desconfiança" (TEPEDINO, 2002, p.XIX) que 
gerava, por força da elevada carga discricionária disposta ao juiz.

Salienta-se, no entanto, no sistema jurídico brasileiro, a partir do surgimento de um Estado assistencialista e intervencionista, o desmantelamento do Código Civil de 1916, cujos setores do texto civil foram cedendo partes inteiras em favor de regramentos especiais ou setorizados da vida interprivados. Reporta-se a esse episódio como sendo a "era dos estatutos" (Estatuto da Terra, Estatuto da Mulher Casada, Estatuto da Criança e do Adolescente, Código de Defesa do Consumidor etc.), para identificar uma nova onda legislativa no País, culminando com a edição da atual Constituição da República (TEPEDINO, 1999, p.8). Três aspectos se destacam no "estatuto": (i) a adoção da técnica legislativa das cláusulas gerais, por meio da qual a "tipificação taxativa dá lugar a cláusulas gerais, abrangentes e abertas"; (ii) o emprego de um linguajar mais setorial e, portanto, menos jurídico; (iii) a redação de normas promocionais ou de sancionamento positivo, não exclusivamente repressivas. (TEPEDINO, 1999, p.8 e 9)

Insta questionar por que razão a desconfiança na elévada discrionariedade do juiz não seria, novamente, o motivo do insucesso da conhecida técnica das cláusulas gerais; e, daí, as opiniões variam. Nesse passo, mostra-se valioso, mais uma vez, o recurso à opinião de Gustavo Tepedino, para quem a atual adoção das cláusulas gerais é de "modo só aparentemente semelhante" àquela historicamente empregada:

O legislador atual procura associar a seus enunciados genéricos prescrições de conteúdo completamente diverso em relação aos modelos tradicionalmente reservados às normas jurídicas. Cuida-se de normas que não prescrevem uma certa conduta mas, simplesmente, definem valores e parâmetros hermenêuticos. Servem assim como ponto de referência interpretativo e oferecem ao intérprete os critérios axiológicos e os limites para a aplicação das demais disposições normativas. (TEPEDINO, 2002, p.XIX)

A meu sentir, há um motivo de cunho mais abrangente para, de um lado, explicar a recusa tácita do emprego e, até mesmo, da adequada compreensão das cláusulas gerais e, por outro prisma, reforçar as esperanças de que agora elas venham a ser empregadas, e tal explicação situa-se no plano constitucional. Vale dizer que, quando de forma mais intensa a técnica em questão começou a ser empregada (década de 1970), o juiz - destinatário evidente das cláusulas gerais - não contava com um adequado suporte axiológico para a construção normativa das regras abertas. $\mathrm{Na}$ fase de surgimento dos Estatutos, vivia-se em regime político não democrático, orientada a ditadura por uma "Constituição" (em verdade um ato constitucional) não legítima, do ponto de vista axiológico, à maioria dos operadores do Direito.

Ora, como bem adverte Gustavo Tepedino ( $O p$. cit., p. XX), a Constituição é a referência de conexão axiológica entre o CC e suas cláusulas gerais, em vista da concretização normativa. Portanto, na ausência de uma legítima Constituição em vigor, faltava ao operador o necessário substrato axiológico para construir o sistema jurídico, uma vez que tais dispositivos de lei são destituídos de conteúdo descritivo e de valor. Assim, em hipótese exemplificativa, se a atual Constituição da República não trouxesse em seu bojo o valor da solidariedade, no inciso I, do seu art. $3^{\circ}$, como fundamento 
da própria República, com grande dificuldade tornar-se-ia eficaz o comando normativo do art. 421 do $\mathrm{CC}^{8},{ }^{8}$ alusivo à função social do contrato. (NALIN, 2001, p.135)

Para além de outros papéis na ordem do sistema, desempenha a atual Constituição brasileira a função de arcabouço axiológico necessário e indispensável para a (justa) operação das cláusulas gerais. Mostra-se insustentável, v.g., descrever a conduta ética reclamada pela cláusula geral de boa-fé, inserida especialmente no art. 422 do $\mathrm{CC},{ }^{9}$ sem que se lance um olhar sobre o teor da ética social anotada na Carta de 1988, magnificamente inserido como fundamento da República Federativa do Brasil.

E seria a ética um valor aplicável ao Direito Civil e, sobretudo, às relações contratuais? Não tenho dúvida ao afirmar que sim, pois, a contrario sensu, sua exclusão das relações interprivadas importaria em insustentável brecha na ordem do sistema jurídico, como se o Direito Civil não se submetesse à totalidade da normativa constitucional (valores, princípios e regras). Por tal razão, enfim, não se pode admitir a existência de subsistemas e, até mesmo, dos tão propagados, por assim dizer, microssistemas jurídicos.

Entretanto, é imprescindível calibrar a influência da normativa constitucional em vista dos múltiplos institutos jurídicos infraconstitucionais. O princípio da autonomia privada encontra seu quadro constitutivo e limitativo na base do art. 170 ,

8. Art. 421. A liberdade de contratar será exercida em razão e nos limites da função social do contrato.

9 Art: 422. Os contratantes são obrigados a guardar; assim na conclusão do contrato, como em sua execução, os princípios de probidade e boa-fé. caput, da Constituição da República; isto porque, se algum dia o referido princípio se posicionou no plano estrito do assim dito Direito Privado, encontra-se ele, hoje, na esfera constitucional. É natural, e faz parte da própria evolução do Direito, a estabilização dos princípios inerentes aos específicos ramos do Direito no âmbito da normativa constitucional, com o passar do tempo, e a conviç̧ão da doutrina e dos tribunais quanto à relevância deles. Esse é um fenômeno do próprio Estado Democrático de Direito (BODIN DE MORAES, 1999, p.105). É o que se nota, por exemplo, com o princípio da propriedade privada (art. 170, inc. II, CR), que acaba sendo, estruturalmente, uma derivação do princípio da autonomia privada. Razão essa pela qual é tão relevante a leitura constitucional do Direito Civil, sem a qual se perde a noção axiológica da sua constitucionalização.

Nem poderia ser diversa a conclusão, uma vez que a autonomia privada decorre, diretamente, da figura de Estado que se impõe e, logo, da sua Carta Constitucional.

Atualmente, quando se pretende ver estabelecido todo o conteúdo social da atual Carta, imperativo compreender o sujeito de direito inserido no contexto social, como, aliás, já aventava Orlando de Carvalho, antes referido, e, para tanto, encarar a configuração da autonomia privada e do direito subjetivo. Para completar o pensamento acerca da autonomia privada, oportuno ler as palavras de Habermas, ao versar sobre o tema, aludindo aos direitos subjetivos:

Direitos subjetivos não estão referidos, de acordo com seu conceito, a indivíduos atomizados e alienados, que se entesam possessivamente uns contra os outros. Como 
elementos da ordem jurídica, eles pressupõem a colaboração de sujeitos, que se reconhecem reciprocamente em seus direitos e deveres, reciprocamente referidos uns aos outros, como membros livres e iguais do direito. Tal reconhecimento recíproco é constitutivo para uma ordem jurídica, da qual é possível extrair direitos subjetivos reclamáveis judicialmente. Neste sentido, os direitos subjetivos são cooriginários com o direito objetivo; pois este resulta dos direitos que os sujeitos se atribuem reciprocamente. (HABERMAS, 1997, p.121)

O mesmo autor alemão, antes citado, transcrevendo Raiser, faz suas as palavras que explicam a conotação constitucional e social da autonomia privada, no contexto do Estado Social:

Tão importante quanto o reconhecimento ético e político de tais posições jurídicas privadas é a introdução do indivíduo, também através do direito, nos contextos de ação regulados por estruturas de ordem, os quais o envolvem e ligam com outros; isso equivale, pois, a formar e garantir os institutos do direito, nos quais o indivíduo assume uma posição de membro. (HABERMAS, 1997, p.120)

Assim, para operar a cláusula geral da função social do contrato, v.g., é absolutamente imprescindível: (i) reconhecer a natureza constitucional da autonomia privada, tendo em vista a que alude expressamente o art. 421 à liberdade de contratar, que nada mais é do que uma verticalização principiológica da autonomia privada, no sentido da concreção do contrato; (ii) compreender que a cláusula geral é dotada de carga principiológica, além de outras, como será visto, sem com eles (princípios), todavia, se confundir.

A autonomia privada não é inflexível ao tempo e ao contexto político de sua constituição. Mesmo num âmbito político e temporal definidos, não se pode conceber que tenha ela idêntico efeito de aplicação, diante da múltipla variedade de relações jurídicas que informa. Por tal razão, v.g., o exercício da autonomia privada contratual (rectius liberdade contratual) de consumo não terá a mesma extensão e profundidade daquela trabalhista, da administrativa, da civil e da empresária. Ainda no seio interno da relação contratual, a leitura que se deve fazer dos princípios (extensão e profundidade) depende do poder de barganha de cada contratante (igualdade material), na específica relação contratual enfocada, para saber se ela cumpre ou não a sua função social, se uma determinada cláusula é abusiva ou não, se agiram as partes em observância à boa-fé etc. Noutros termos, a medida interpretativa da autonomia privada contratual depende da verificação casuística da relação contratual, da relação e da medida de igualdade entre os contratantes.

Além disso, faz-se necessário calibrar o mecanismo aplicativo da normativa constitucional em vista das particularidades dos institutos interprivados fundamentais (propriedade, família, contrato e, mais recentemente, a sociedade empresa), sem dela, entretanto, jamais prescindir.

Essa é a necessária simbiose entre a normativa constitucional e a infraconstitucional, neste trabalho evidenciada a normativa civil, a qual, obviamente, não se limita ao CC, sendo a cláusula geral uma técnica para manter todo o sistema aberto e oxigenado.

Explica Judith Martins-Costa que cláusula geral vem a ser:

[...] o meio legislativamente hábil para permitir o ingresso, no ordenamento jurídico de princípio valorativos, expressos ou ainda inexpressos legislativamente, de standars, máximas de conduta, arquétipos exemplares de 
comportamento, das normativas constitucionais e de diretivas econômicas, sociais e políticas, viabilizando a sua sistematização no ordenamento positivo. ${ }^{10}$ (MARTINS-COSTA, 1999, p.274)

Nas palavras de Gustavo Tepedino (2002, p.XIX.), "Cuida-se de normas que não prescrevem uma certa conduta, mas, simplesmente, definem valores e parâmetros hermenêuticos. Servem assim como ponto de referência interpretativo e oferecem ao intérprete os critérios axiológicos e os limites para a aplicação de demais disposições normativas".

Experiência legislativa anterior já apontava para conceitos abertos ou indeterminados, inseridos em preceitos casuísticos, os quais não se confundem com as cláusulas gerais. A causa de ser do conceito indeterminado é a de manter a regra jurídica sempre atualizada aos novos valores sociais (v.g. o conteúdo ético de mulher honesta, para fins criminais), adaptando a regra àqueles vigentes no momento da sua concreção, havendo, de qualquer maneira, previsão da conclusão (sancionamento) para a hipótese de alinhamento ou não do fato ao preceito, evidentemente, de conteúdo ou com elementos indeterminados. Motivo pela qual arremata Judith Martins-Costa que "[...] não haverá, aí, 'criação do direito' por parte do juiz, mas apenas interpretação"."1

Sendo assim, o papel do magistrado diante de uma cláusula geral não é o de simplesmente interpretar a regra por meio de critérios ou de valores sociais contemporâneos.
Cabe-lhe "[...] concorrer ativamente para a formulação da norma", 12 inclusive, para fins de estabelecimento das conseqüências jurídicas da sua violação, ou, em outras palavras, para dizer qual será a sanção mais adequada a ser imposta, quando menos a sua extensão ao caso concreto. Assim ocorre na análise do já mencionado art. 421 do CC, que, ao versar sobre a necessidade das partes em guardarem o exercício da liberdade contratual em razão e nos limites da função social do contrato, absolutamente nada dispõe sobre qual será a conseqüência jurídica por força da não verificação da função social em dada relação contratual. $\mathrm{Na}$ base da tradição civilística, tal conseqüência, a ser construída pelo julgador, passaria, ou por uma das ineficácias jurídicas (inexistência, invalidade e ineficácia - $s s^{-}$), ou pela conversão do negócio jurídico (art. $170 \mathrm{CC}$ ), talvez pelo cumprimento coativo da obrigação ou, por fim, pelas figuras da reparação civil.

Note-se, portanto, que, na hipótese específica do art. 421 CC, o deseńho da cláusula geral está a impor ao magistrado que descreva, a partir do caso concreto, o significado de função social do contrato, constate a sua observância ou não pelas partes e declare a conseqüência por força da sua inobservância. Todos os lances conceituais, enfim, estão a cargo do juiz, merecendo uma incomparável atenção deste, em contrataste ao antigo Código, no que tange à instrução do processo civil. Por isso, o processo civil contemporâneo está muito mais próximo da verdade real do que da verdade meramente formal.

\footnotetext{
${ }^{10}$ MARTINS-COSTA, J. 1999, p.274.

11 Ibidem, p.326.
}

12 Ibidem, p.326-327. 
Finalizo esta parte com as palavras do Gustavo Tepedino: “[...] as cláusulas gerais do novo Código Civil poderão representar uma alteração relevante no panorama do direito privado brasileiro desde que lidas e aplicadas segundo a lógica da solidariedade constitucional e da técnica interpretativa contemporânea", 13 com o que se está de pleno acordo, pois é a Constituição que poderá gerar a ampla operação do CC e a modificação no (insuportável) estado social das coisas. Sem a constitucionalização do Direito Civil, o CC poderá ser aplicado de qualquer maneira, contudo, de forma neutra, destituída da propagada "ética da situação" (REALE, 2000, p.42), grande justificativa para termos um novo texto civil.

\section{DISCRICIONARIEDADE JUDICIAL,} RESPONSABILIDADE DO MAGISTRADO E SEGURANÇA JURÍDICA

A função do juiz, em vista do novo prisma que para ele se abre, após o CC, tem um maior destaque em relação à sua condição anterior diante do caso civil. Curioso como poucas cláusulas gerais puderam acarretar tamanha modificação na atividade judiciária cível, sendo fundamental, também, observar a imensa dose de responsabilidade social que hoje, mais do que nunca, traz consigo a magistratura.

É claro que a atividade constitucional do juiz de direito sempre terá peso num Estado Democrático de Direito, respeitoso da tripartição do Poder do Estado. "Hoje, e mais no futuro, o juiz está sendo argüido pela

\footnotetext{
${ }^{13}$ Op. Cit, p.XX.
}

sociedade por seus atos e atitudes e são muito importantes, e decisivos no contexto social" (ROSAS, 2003, p.611). Mas não escapa ao olhar de todos a situação social caótica vivenciada pelo Brasil, a qual, com muita esperança, ainda levará um bom tempo para mudar. O fracasso do legislador ao editar 'leis' de modo "inflacionário" também é o da magistratura, pois, em vista da inércia que "movimenta" as lides civis, nada pode-se fazer, antes de ser provocado pelo interessado ou ofendido. A sociedade, sedenta de justiça, entende a inércia como omissão, havendo, de outro lado, algum espaço para mudar esta má compreensão dos limites da atuação jurisdicional, em vista do sistema de cláusulas gerais.

Assim, a figura legislativa das cláusulas gerais, que hoje norteia o $\mathrm{CC}$, pode servir como instrumento de modificação social, ainda que sem ofensa a princípios fundamentais da processualista civil, tais como o da inércia e o da imparcialidade e, sobretudo, sem que isto se revele em abusiva discricionariedade do julgador.

Alinham-se às cláusulas geraị com o Estado Social, uma vez que delas pode-se extrair uma conseqüência premial ou positiva, na medida em que o quadro normativo em que estão inseridas não trata de sancionar (negativamente) as condutas, sendo, aliás, missão do magistrado não proceder de maneira estática diante de normas de tal envergadura, em vista da finalidade social da lei e dos programas que busca executar. (PÁDUARIBEIRO, 2003, p.123).

Veja-se, para uma compreensão melhor, a operação da indisfarçável cláusula geral que é o art. 422 do CC, ao tratar do princípio da boa-fé. Assim, dispõe o artigo de lei: $O s$ 
contratantes são obrigados a guardar, assim na conclusão do contrato, como em sua execução, os princípios de probidade e boafé. Na leitura do artigo, mostra-se clara a necessidade do magistrado em (re)construtir o processo contratual, a partir da conduta das partes (vertente objetiva da boa-fé), uma vez que a boa-fé, dentre outras várias funções, também é constitutiva de deveres contratuais, os quais podem ser violados. Compete ao juiz da causa, destarte, verificar, sobretudo, se as partes cumpriram o contrato pelo modo devido, investigando a qualidade e a quantidade da carga obrigacional executada, em comparação ao que previram na formação do contrato (vertente subjetiva da boa-fé) $)^{14}$ e, mesmo antes, nas tratativas preliminares. ${ }^{15}$

A construção do conceito de boa-fé somente é possível à luz do caso concreto, servindo para uma exclusiva relação contratual, em vista das particulares condutas dos operadores da relação. Então, compete

${ }^{14}$ Oportuno esclarecer que o princípio da boafé é dotado de duas cargas distintas, uma subjetiva e outra objetiva. Tem sido destacado pela doutrina mais recente, após a edição do $\mathrm{CC}$, o aspecto objetivo da boa-fé, sem que se dê devida importância ao seu plano subjetivo. Não parece correto "esquecer" do plano subjetivo da boa-fé, pois ela encerra, sim, ainda hoje, destacado papel na contratação, notadamente nas tratativas preliminares e na formação do contrato. Ao abordar aspectos posteriores à vigência do $\mathrm{CC}$, sustenta Miguel Reale que a boa-fé objetiva resulta da intencionalidade ou do "[...] propósito de guardar fidelidade ou lealdade ao passado" (Op. Cit., p.77).

15 A boa-fé acarreta para o contrato deveres laterais ou correlatos, os quais podem ser violados (violação positiva do contrato), implicando a quebra total ou parcial do contrato, gerando, por conta disso, ou exceções contratuais ou responsabilidade civil, como já tive a oportunidade de anotar (In responsabilidade civil: descumprimento do contrato e dano extrapatrimonial, Juruá: Curitiba, 1996). ao juiz construir tal desenho normativo, o que é "[...] um trabalho bem mais complexo do que o da simples subsunção". (AGUIAR JÚNIOR, 1999, p.10)

Para o desenvolvimento de tal atividade, relativamente nova, é necessário que o juiz defina a norma, vale dizer, construa a norma; sendo que o seu conteúdo deverá ser específico e particular ao caso, para, depois disso, fazer a subsunção da conduta em relação ao preceito por ele edificado (AGUIAR JUNIOR, idem). É bem verdade que a técnica positivista do silogismo de subsunção, por meio do qual se acentua o pensamento axiomático-dedutivo, não mais encontra ampla repercussão entre mentes oxigenadas, servindo, apenas, para convencer, e não para demonstrar. A técnica mais empregada, atualmente, é a da lógica dialética ou a da argumentação, com a qual se faz o constante debate entre a norma aplicável e os valores do caso concreto (AMARAL, 2003, p.84), muito ao gosto do que se vem propagando para o uso das cláusulas gerais.

Mas a fundamentação do ato decisório, especificamente para a hipótese normativa do art. 422, não está nela em si. Em outras palavras, não haverá fundamentação válida do decisum se o juiz simplesmente se referir ao mencionado artigo de lei, concluindo pela inobservância da boa-fé por um dos contratantes, para então declarar alguma conseqüência judicial. Será imprescindível que a fundamentação localize no sistema jurídico como um todo, dentro ou fora do $\mathrm{CC}$, as matizes sociais que levam à conclusão de se estar diante de um comportamento desconforme à boa-fé. A Constituição é o berço natural de tais fundamentos axiológicos, sendo adequado e oportuno a ela recorrer o 
magistrado para tratar de tais aspectos conceituais, não raramente revestidos de puros juízos éticos.

A discricionariedade será abusiva na falta de fundamentação ou na fundamentação que ocorre pelo sistema da subsunção clássica, sem prévia construção do conteúdo normativo para o caso concreto, quando se estiver diante de uma cláusula geral. Sem dúvida, o CC não é dotado somente de cláusulas gerais, mas de um misto destas e, também, de regras de casuística, devendo estar atento o magistrado para o modelo normativo com o qual está lidando, para não incorrer a decisão em posterior invalidade.

Não há razão para se desconfiar da atuação do juiz, ao gosto de uma mofada exegese positivista, a qual, em verdade, depositou toda a sua confiança no legislador e, por oposição, sua absoluta desconfiança na atividade do magistrado. A técnica de cláusula geral não renuncia ao garantismo da fundamentação dos atos decisórios previsto pela Carta (art. 93, IX). E, assim, não haverá conduta abusiva por parte do magistrado, desde que ele fundamente sua decisão, como de costume, seguindo os passos anteriormente sugeridos.

A posição contemporânea do magistrado não pode ser encarada com desconfiança e, muito menos, com espanto; até porque, tanto em sistemas estrangeiros como no brasileiro, observa-se uma acentuada evolução no papel do juiz, diante da construção do sistema jurídico. Em apertada síntese, inicialmente, na Europa, havia a rígida divisão dos Poderes do Estado, conforme apregoado por Charles Montesquie, figurando o juiz como a "boca do legislador", situação que perdurou até meados do século XIX. Na seqüência, a partir do início do séc. XX, e apesar da retrógrada posição codicista, o magistrado passou a ser o intérprete da lei. Ainda no início do século passado, surgiram duas escolas fundamentais na Alemanha, com base na Teoria Geral do Direito e da Metodologia Jurídica Geral. Da primeira (Teoria Geral do Direito) emergiu a assim chamada Escola do Direito Livre (R. Stammler), postulando pela existência de um "juiz régio", o qual poderia mesmo ignorar a lei, em alguns casos, quando esta correspondesse às novas idéias sociais. A segunda, encabeçada por Gustav Radbrusch, pregava o "método de interpretação objetiva": o "teor da literal, a gênese, a sistemática e, sobretudo, a telos, a ratio, a finalidade da lei, deveria (sic) ser os critérios por meio dos quais o sentido da lei precisava ser identificado." (STERN, 2003, p.513)

Tal evolução do papel do juiz, ainda esclarece Klaus Stern, serviu de estofo para a construção de um sistema de Direito Constitucional, na Alemanha, fundado na participação do juiz, no qual ele cria o Direito, assim chamado de "direito judicial" (STERN, Op. Cit., p.513). A forma de ver a atuação do juiz, num plano de construção do sistema, decorre da constatação de serem imperfeitas as leis, impondo uma interpretação inclinada ao aperfeiçoamento do Direito, ainda que o sistema seja fundado no modelo codificado.

Na mesma linha do Direito Constitucional comparado, evidencia-se, no Brasil, o equilíbrio constitucional e harmônico entre os Poderes do Estado. A CR é expressa ao apresentar um quadro de harmonia e igualdade, quando aborda a divisão dos Poderes do Estado, nos termos do art. $2^{\circ}$, caput, o que destoa de outras constituições européias, nas quais o juiz aparece como sujeito "vinculado à lei" 
(STERN, Op. Cit., p.506). Em outros termos, v.g., na Alemanha, o juiz não se encontra em linha de igualdade com o legislador, em que pese a constituição daquele país se referir ao papel da jurisprudência e enunciados de princípios, tendo sido lento e gradual o engrandecimento da figura do juiz naquela sociedade. Portanto, é preciso desfrutar do ambiente constitucional brasileiro para confirmar que a segurança jurídica contemporânea (se é que existe algum conceito uno de segurança jurídica ${ }^{16}$ ) transitou da figura da segurança na lei para a segurança no juiz, o que se apresenta, em meu entendimento, mais honesto, sob o aspecto da aplicação ideológica da lei (não neutra), e mais coerente com os anseios de uma sociedade que não é geral e, muito menos, abstrata (características essenciais da lei), mas sim concreta e localizada, como de fato são concretos os sujeitos e localizados os problemas da vida.

Destarte, não pode ser encarada com sobressaltos e reprovações a construção do (novo) sistema de Direito Civil pelas mãos do juiz, pois, dentre outras, esta também é uma missão constitucional da magistratura.

\section{CONCLUSÃO}

O Direito Civil vive uma fase muito rica, pois, se o CC em vigor não é fruto de uma unanimidade, e seria surpreendente se o fosse,

\footnotetext{
16 Assim como referir "um" conceito sobre a ética, encontrar "um" conceito sobre segurança jurídica se mostra tão improvável quanto definir "justiça". Todas são expressões vazias de contexto individual e dependentes de conceitos ou elementos conceituais externos a elas próprias. Sobre a flexibilidade do "conceito de justiça", por exemplo, ver Karl Engish (1988, p.218).
}

e mesmo que extremamente combatido por vários segmentos do Direito, em particular ao longo dos últimos momentos de sua tramitação pelo Senado e Congresso Nacional, trouxe o Código novos ventos, renovadores da reflexão sobre este tão relevante ramo do Direito.

Assim como ocorrido no séc. XX viramos este novo século debatendo o Direito Civil, mas não com base liberal patrimonialista, uma vez que, nem de longe, é a atual configuração do Estado brasileiro. O Direito Civil contemporâneo sofre incontestável influxo da normativa constitucional, sendo inadmissível encará-lo aos moldes da codificação de 1916. Se existe um novo diploma civil, assim o é porque impera uma ética nas relações sociais, compatível com os valores brasileiros do atual século e não com aqueles do final do século XIX e início do século XX.

$\mathrm{Na}$ construção do novo Direito Civil, mostra-se relevante a nova codificação, sendo que dela surgem possibilidades concretas para efetivar os valores inseridos na Carta, pois o que faz o CC é exatamente servir de instrumento para tal fim.

A técnica de cláusula geral será decisiva para uma construção do sistema jurídico comprometido com a realidade social concreta e contemporânea.

O juiz merece a confiança dos operadores do Direito, carecendo-lhe, no entanto, melhor compreender o seu papel e a sua responsabilidade social, por não ser ele um mero "aplicador da lei", mas, de outro viés, um construtor do sistema jurídico, gozando de status constitucional para tanto. 


\section{REFERÊNCIAS}

AMARAL, F. Direito civil: introdução. 5.ed. Rio de Janeiro: Renovar, 2003.

AZEVEDO, P. F. de. Crítica à dogmática e hermenêutica jurídica. Porto Alegre: Fabris, 1989.

BARCELLONA, P. Diritto privato e società moderna. Nápoles: Jovene, 1996.

COELHO, L. F. Saudade do futuro:

transmodernidade, direito, utopia. Florianópolis:

Boiteaux, 2001.

ENGISH, K. Introdução ao pensamento jurídico. 6.ed. Lisboa: Gulbenkian, 1988.

FACHIN, L. E. Teoria crítica do direito civil. Rio de Janeiro: Renovar, 2000.

FINGER, J. C. Constituição e direito privado: algumas notas sobre a chamada constitucionalização do direito civil. A constituição concretizada: construindo pontes entre o público e o privado. Porto Alegre: Livraria do Advogado, 2000. p.85-106.

FLÓREZ-VALDÉS, J. A. El derecho civil constitucional. Madri: Civitas, 1991.

GIULIANI, A.; PALAZZO, A. e FERRANTI, I. $L$ interpretazione della norma civile. Torino: Giappichelli, 1996.

HABERMAS, J. Direito e democracia: entre facticidade e realidade I. Rio de Janeiro: Tempo Brasileiro, 1997.

IRTI, N. L'età della decodificazione. 2. ed. Milão: Giuffrè, 1986.

MONATERI, P. G. Pensare il dirito civile. Torino: Giappichelli. 1997.

MARTINS-COSTA, J. A boa-fé no direito privado: sistema e tópica no sistema obrigacional. São Paulo: Revista dos Tribunais, 1999.

MARTINS-COSTA, J. e BRANCO, G. L. C. Diretrizes teóricas do novo código civil brasileiro. São Paúlo: Saraiva, 2002.
MORAES, M. C. B. de. Constituição e direito civil: tendências. Direito, Estado e Sociedade. Rio de Janeiro: PUC/RJ, v.15, 1999. p.95-113.

NALIN, P. Responsabilidade civil: descumprimento do contrato e dano extrapatrimonial. Juruá: Curitiba, 1996.

NALIN, P. Do contrato: conceito pós-moderno (em busca de sua formulação na perspectiva civil-constitucional). Curitiba: Juruá, 2001.

PÁDUA RIBEIRO, A. de. O judiciário como poder político do século XXI. Estudos em homenagem a Carlos Alberto Menezes Direito. Rio de Janeiro: Renovar, 2003. p.111-128.

PERLINGIERI, P. 'Depatrimonializzazione' e diritto civile. Scuole, tendenze e metodi: problemi del diritto civile. Nápoles: ESI, 1983. p.175-178.

REALE, M. O projeto do novo Código Civil situação após a aprovação pelo Senado Federal. São Paulo: Saraiva, 2000.

AGUIAR JÚNIOR, R. R. de. O poder judiciário e concretização das cláusulas gerais: limites e responsabilidade. Palestra proferida na faculdade de Direito da UFRGS, 29.11.1999.

ROSAS, R. Funções essenciais à justiça e conduta ética. Estudos em homenagem a Carlos Alberto Menezes Direito. Rio de Janeiro:

Renovar, 2003. p.609-615.

STERN, K. O juiz e aplicação do direito. Direito constitucional: estudos em homenagem a Paulo Bonavides. $2^{\mathrm{a}}$ tiragem. São Paulo: Malheiros, 2003. p.505-515.

TEPEDINO, G. Introdução: crise de fontes normativas e técnica legislativa na parte geral do código civil de 2002. A parte geral do novo código civil: estudos na perspectiva civilconstitucional. Rio de Janeiro: Renovar, 2002. XV-XXXIII.

TEPEDINO, G. Temas de direito civil. Rio de Janeiro: Renovar, 1999. 